\title{
ОСОБЛИВОСТІ ФУНКЦІОНАЛЬНОГО СТАНУ ПЕЧІНКИ У ЩУРІВ РІЗНОГО ВІКУ ЗА УМОВИ ДІЇ ТЮТЮНОВОГО ДИМУ НА ТЛІ ЗАСТОСУВАННЯ НАТРІЙ ГЛУТАМАТУ
}

Вступ. Тютюнокуріння щорічно вбиває понад 8 млн осіб у всьому світі, з них близько 1,2 млн є пасивними курцями. Характерна ознака сучасних харчових технологій - використання харчових добавок, які не завжди безпечні для здоров'я людини.

Мета дослідження - вивчити вплив пасивного тютюнокуріння на тлі тривалого введення натрій глутамату на показники фрункціонального стану печінки у сироватці крові щурів різного віку.

Методи дослідження. Досліди виконано на 32 безпородних статевозрілих білих щурах-самцях масою 180-200 г та 32 безпородних статевонезрілих білих щурах-самцях масою 60-80 г. Тварин поділили на 4 групи: 1-ша - контрольна; 2-га - щури, яким моделювали пасивне тютюнокуріння; 3-тя - щури, яким вводили натрій глутамат; 4-та - щури, яким моделювали пасивне тютюнокуріння на тлі введення натрій глутамату. В сироватці крові щурів визначали вміст загального білірубіну, активність лужної фросоратази (ЛФ) та активність аланінамінотрансфрерази (АлАТ).

Результати й обговорення. За умови пасивного тютюнокуріння у сироватці крові статевозрілих щурів вміст загального білірубіну вірогідно зменшився на 35,3 \%, активність ЛФ достовірно підвищилася на 38,3 \%, активність АлАТ вірогідно зросла у 2,6 раза, що свідчило про порушення фрункціонального стану печінки та розвиток цитолізу і холестазу. Пасивне тютюнокуріння на тлі застосування натрій глутамату супроводжувалося зменшенням вмісту загального білірубіну на 55,3 \%; $p<0,001$ відносно контрольної групи, що на 31,0% (p=0,002) нижче цього показника за умови ізольованої дії тютюнового диму; зростанням активності ЛФ у 2,1 раза; $p<0,001$ щодо контрольної групи, що на 53,2 \% (p<0,001) перевищувало дані за умови ізольованої дії тютюнового диму; збільшенням активності АлАТ у 4,5 раза; $p<0,001$ стосовно контрольної групи, що на 68,8 \% ( $p<0,001)$ перевищувало показник за умови ізольованої дії тютюнового диму. В статевонезрілих щурів при цьому інтенсивність змін біохімічних маркерів орункціонального стану печінки перевищувала показники статевозрілих щурів.

Висновки. Отримані результати свідчать про те, що натрій глутамат посилює токсичний вплив тютюнового диму на печінку, це проявляється більш вираженими змінами біохімічних маркерів їі фрункціонального стану за умови комбінованої дії тютюнового диму та натрій глутамату відносно ізольованої дії тютюнового диму. У віковому аспекті більш виражені зміни спостерігають у статевонезрілих щурів.

КЛЮЧОВІ СЛОВА: пасивне тютюнокуріння; натрій глутамат; фрункціональний стан печінки; біохімічні маркери.

ВСТУП. За оцінками Всесвітньої організації охорони здоров'я, тютюнокуріння щорічно вбиває понад 8 млн чоловік у всьому світі, з них близько 1,2 млн є пасивними курцями [1]. В Європейському регіоні майже 0,7 млн смертей на рік пов'язані з уживанням тютюну [2], а в Україні в результаті куріння щорічно вмирає близько 120 тис. осіб [3]. Особливо небезпечними є ранній вік початку куріння і висока поширеність тютюнокуріння серед дітей та підлітків [4, 5]. Європейське опитування учнівської молоді (c) Н. В. Гецько, Т. Я. Ярошенко, 2021. щодо вживання алкоголю та інших наркотичних речовин (ESPAD), проведене в Україні в 2019 р., показало, що частка молодих людей, які курили хоча б один раз у житті, становила $56,2 \%$ серед юнаків і 45,1 \% серед дівчат. Крім того, згідно 3 дослідженням, вік першої спроби куріння становив 14 років для кожного восьмого підлітка $(12,1 \%)[6]$.

Печінка $є$ основним органом, на який опосередковано впливає куріння. Тютюновий дим містить близько 2500 сполук (серед них поліциклічні ароматичні вуглеводні; азаарени; N-нітро- 
заміни; ароматичні аміни; акрилонітрил, кротональдегід, вінілхлорид, фрормальдегід, бензин; монооксид вуглецю, ціанід, сульфрід вуглецю, миш'як, нікель, кадмій, хром, свинець, полоній-210). Приблизно 600 сполук додають до тютюну в процесі виробництва цигарок. Крім речовин, що входять до складу тютюну та які додають до цигарок у процесі їх виробництва, ціла низка сполук утворюється в процесі згорання сигарети, і під час куріння людина вдихає до 4000 сполук із різноспрямованою дією [7].

За даними A. Akhavan Rezayat та співавт., тютюнокуріння асоціюється із захворюваннями печінки, такими, як новоутворення і хронічні запальні захворювання [8]. Інші дослідники також вказують на наявність взаємозв'язку між курінням сигарет і тяжкістю перебігу хронічних захворювань печінки $[9,10]$. Водночас $є$ дані про те, що тютюновий дим не впливає на активність трансаміназ [11, 12].

3 іншого боку, характерною ознакою сучасних харчових технологій є використання харчових добавок, які виконують технологічні фрункції, поліпшують органолептичні властивості харчових продуктів і не завжди є безпечними для здоров'я людини. Однією з найпоширеніших харчових добавок як в Україні, так і в Європі $€$ натрій глутамат [13]. Реальна загроза одночасного надходження в організм тютюнового диму і натрій глутамату надає вивченню їх поєднаної дії особливої актуальності.

Мета дослідження - вивчити вплив пасивного тютюнокуріння на тлі тривалого введення натрій глутамату на показники фрункціонального стану печінки у сироватці крові щурів різного віку.

МЕТОДИ ДОСЛІДЖЕННЯ. ДослідИ виконано на 32 безпородних статевозрілих білих щурахсамцях масою 180-200 г та 32 безпородних статевонезрілих білих щурах-самцях масою 60-80 г. Усіх тварин поділили на 4 групи: 1-ша контрольна (n=8); 2-га - щури, яким моделювали пасивне тютюнокуріння (n=8); 3-тя - щури, яким вводили натрій глутамат (n=8); 4-та - щури, яким моделювали пасивне тютюнокуріння на тлі введення натрій глутамату $(\mathrm{n}=8)$.

Вплив тютюнового диму (пасивне тютюнокуріння) моделювали шляхом поміщення щурів у спеціально сконструйовану камеру з оргскла об'ємом 30 л, що дозволило обкурювати тварин у вільній поведінці. Задимлення проводили, спалюючи 2 сигарети "Прима срібна (червона)" (смоли - 10 мг/сиг., нікотин - 0,8 мг/сиг.). У камері одночасно перебували 4 тварини. Піддослідні щури проходили процедуру пасивного тютюнокуріння 2 рази на добу по 30 хв. Після закін- чення кожного 30-хвилинного сеансу тварин витягали 3 камери і поміщали в стандартну клітку віварію. Тривалість експерименту становила 30 днів [14, 15].

Тваринам 3-ї дослідної групи протягом 30 днів внутрішньошлунково вводили у дозі 30 мг/кг натрій глутамат, розчинений у 0,5 мл дистильованої води кімнатної температури [16].

Щурам 4-ї дослідної групи моделювали пасивне тютюнокуріння і вводили натрій глутамат протягом 30 днів.

Контролем слугувала група інтактних тварин.

Усі маніпуляції проводили 3 дотриманням принципів біоетики відповідно до положення Європейської конвенції про захист хребетних тварин, що використовуються для дослідних та інших наукових цілей (Страсбург, 1986).

У сироватці крові визначали вміст загального білірубіну, активність лужної фросфратази (ЛФ) та активність аланінамінотрансорерази (АлАТ) на напівавтоматичному біохімічному аналізатоpi "Humalyzer 2000" ("Нuman", Німеччина) за допомогою стандартних наборів реактивів і виражали в мкмоль/л та Од/л відповідно.

Статистичну обробку цифрових даних здійснювали за допомогою програмного забезпечення Excel ("Microsoft", США) і STATISTICA 6.0 ("Statsoft", США). Зважаючи на непараметричний розподіл кількісних характеристик, дані наводили у вигляді медіани і квартилів (нижнього та верхнього) - Me (Lq; Uq). Порівняльний аналіз 4 підгруп здійснювали з використанням непараметричного критерію Краскела - Уолліса. Отримавши його вірогідні значення $(p<0,05)$, подальше попарне порівняння груп проводили із застосуванням критерію Манна - Уїтні з урахуванням поправки Бонорерроні при оцінюванні значень $\mathrm{p}$.

РЕЗУЛЬТАТИ Й ОБГОВОРЕННЯ. ПрИ ПОріВнянні вмісту загального білірубіну та активності АлАТ у сироватці крові статевозрілих і статевонезрілих щурів контрольних груп вірогідних відмінностей не встановлено. Щодо активності ЛФ, то цей показник у статевонезрілих щурів на 29,8 \% достовірно перевищував дані статевозрілих тварин контрольної групи (табл. 1, 2).

За умови пасивного тютюнокуріння вміст загального білірубіну в сироватці крові статевозрілих щурів вірогідно зменшився на 35,3 \% відносно контрольної групи (див. табл. 1). Пасивне тютюнокуріння на тлі застосування натрій глутамату супроводжувалося більш вираженим його зменшенням (на 55,3 \%; $p<0,001$ ) відносно контрольної групи, що на $31,0 \%(p=0,002)$ нижче даного показника за умови ізольованої дії тютюнового диму. При цьому ізольоване введен- 
ня натрій глутамату зумовило достовірне зменшення вмісту загального білірубіну в сироватці крові на 42,8 \% порівняно з контрольними тваринами.

У статевонезрілих щурів за умови пасивного тютюнокуріння вміст загального білірубіну у сироватці крові вірогідно зменшився на 47,5 \% відносно контрольної групи (див. табл. 2). Пасивне тютюнокуріння на тлі застосування натрій глутамату супроводжувалося більш вираженим його зниженням (на 61,2 \%; p<0,001) щодо контрольної групи, що на 26,1 \% (p=0,002) менше даного показника при ізольованій дії тютюнового диму та на 23,6 \% ( $p=0,003)$ нижче даного показника за умови тривалого введення натрій глутамату. При цьому ізольоване введення натрій глутамату зумовило достовірне зменшення вмісту загального білірубіну в сироватці крові на 49,2 \% порівняно $з$ контрольними тваринами.

У віковому аспекті інтенсивність змін вмісту загального білірубіну в сироватці крові перевищувала показники статевозрілих щурів за умови пасивного тютюнокуріння на 12,2 \%, при тривалому введенні натрій глутамату - на 6,4 \%, за умови пасивного тютюнокуріння на тлі застосування натрій глутамату - на 5,9% відповідно.
$€$ дані, що білірубін має антиоксидантні властивості [17] і його вміст у сироватці крові щурів дослідних груп, імовірно, знизився внаслідок гіперпродукування вільних радикалів за умови дії обох досліджуваних чинників. Наші результати співзвучні з результатами K. S. Alsalhen та R. D. Abdalsalam, які також відзначили зменшення вмісту загального білірубіну в сироватці крові курців відносно осіб, які не курять, незалежно від рівня гемоглобіну [18]. Аналогічними є дані щодо впливу натрій глутамату на вміст білірубіну. Зокрема, M. S. Tawfik i N. Al-Badr показали, що вплив натрій глутамату в низьких дозах (0,6 та 1,6 мг/г маси) зумовив зменшення вмісту загального білірубіну у сироватці крові щурів на 10,3 і 20,6 \% відповідно до дози введення [19].

Лужна фросфратаза є першорядним ензиматичним маркером холестазу [20]. За умови пасивного тютюнокуріння її активність у сироватці крові статевозрілих щурів вірогідно підвищилася на 38,3 \% відносно контрольної групи. Пасивне тютюнокуріння на тлі застосування натрій глутамату супроводжувалося більш вираженим її зростанням (у 2,1 раза; $р<0,001)$ щодо контрольної групи, що на 53,2% (p<0,001) перевищувало

Таблиця 1 - Вплив тютюнового диму і натрій глутамату на показники фрункціонального стану печінки у сироватці крові статевозрілих щурів

\begin{tabular}{|c|c|c|c|c|}
\hline \multirow{3}{*}{ Показник } & \multicolumn{4}{|c|}{ Гррупа тварин } \\
\hline & 1-ша & 2-га & 3-тя & 4-та \\
\hline & контрольна & пасивне тютюнокуріння & натрій глутамат & $\begin{array}{c}\text { пасивне тютюнокуріння+ } \\
\text { натрій глутамат }\end{array}$ \\
\hline $\begin{array}{l}\text { Загальний } \\
\text { білірубін, } \\
\text { мкмоль/л }\end{array}$ & $\begin{array}{c}47,58 \\
(46,25 ; 50,80)\end{array}$ & $\begin{array}{c}30,80 \\
(26,95 ; 32,00) \\
p_{1-2}<0,001^{*}\end{array}$ & $\begin{array}{c}27,20 \\
(22,70 ; 27,90) \\
p_{1-3}<0,001^{*} \\
p_{2-3}=0,041\end{array}$ & $\begin{array}{c}21,25 \\
(17,30 ; 22,30) \\
\mathrm{p}_{1-4}<0,001^{*} \\
\mathrm{p}_{2-4}=0,002^{*} \\
\mathrm{p}_{3-4}=0,037\end{array}$ \\
\hline \multicolumn{5}{|c|}{ Критерій Краскела - Уолліса, p (H=24,22; p<0,001*) } \\
\hline ЛФ, Од/л & $\begin{array}{c}197,00 \\
(175,65 ; 230,50)\end{array}$ & $\begin{array}{c}272,50 \\
(254,00 ; 349,50) \\
\mathrm{p}_{1-2}<0,001^{*}\end{array}$ & $\begin{array}{c}256,00 \\
(227,50 ; 280,00) \\
p_{1-3}=0,016 \\
p_{2-3}>0,05\end{array}$ & $\begin{array}{c}417,50 \\
(343,50 ; 489,50) \\
p_{1-4}<0,001^{*} \\
p_{2-4}=0,016 \\
p_{3-4}=0,002^{*}\end{array}$ \\
\hline \multicolumn{5}{|c|}{ Критерій Краскела - Уолліса, p (21,83; p<0,001*) } \\
\hline АлАТ, Од/л & $\begin{array}{c}69,55 \\
(53,15 ; 76,45)\end{array}$ & $\begin{array}{c}184,00 \\
(171,00 ; 220,50) \\
p_{1-2}<0,001^{*}\end{array}$ & $\begin{array}{c}113,00 \\
(100,00 ; 140,00) \\
p_{1-3}<0,001^{*} \\
p_{2-3}<0,001^{*}\end{array}$ & $\begin{array}{c}310,50 \\
(298,00 ; 315,00) \\
p_{1-4}<0,001^{*} \\
p_{2-4}<0,001^{*} \\
p_{3-4}<0,001^{*}\end{array}$ \\
\hline \multicolumn{5}{|c|}{ Критерій Краскела - Уолліса, p (H=29,11; p<0,001*) } \\
\hline
\end{tabular}

Примітки. Тут і в таблиці 2:

1. $\mathrm{p}_{1-2}, \mathrm{p}_{1-3}, \mathrm{p}_{1-4}-$ вірогідність відмінностей між контрольною і дослідними групами; $\mathrm{p}_{2-3}, \mathrm{p}_{2-4}$ - вірогідність відмінностей між групою 3 тютюнокурінням і групою 3 введенням натрій глутамату та групою 3 тютюнокурінням на тлі введення натрій глутамату; $p_{3-4}$ - вірогідність відмінностей між групою з введенням натрій глутамату і групою з тютюнокурінням на тлі введення натрій глутамату.

2. Рівень достовірності при попарному порівнянні груп для критерію Манна - Уїтні згідно з поправкою Бонферроні $\mathrm{p}<0,008$.

3. * - статистично значущі результати. 
Таблиця 2 - Вплив тютюнового диму і натрій глутамату на показники функціонального стану печінки у сироватці крові статевонезрілих щурів

\begin{tabular}{|c|c|c|c|c|}
\hline \multirow{3}{*}{ Показник } & \multicolumn{4}{|c|}{ Група тварин } \\
\hline & 1-ша & 2-га & 3-тя & 4-та \\
\hline & контрольна & пасивне тютюнокуріння & натрій глутамат & $\begin{array}{c}\text { пасивне тютюнокуріння+ } \\
\text { натрій глутамат }\end{array}$ \\
\hline $\begin{array}{l}\text { Загальний } \\
\text { білірубін, } \\
\text { мкмоль/л }\end{array}$ & $\begin{array}{c}44,95^{\#} \\
(44,06 ; 46,40)\end{array}$ & $\begin{array}{c}23,60^{\#} \\
(21,30 ; 26,30) \\
\mathrm{p}_{1-2}<0,001^{*}\end{array}$ & $\begin{array}{c}22,85 \\
(20,75 ; 24,35) \\
\mathrm{p}_{1-3}<0,001^{*} \\
\mathrm{p}_{2-3}>0,05\end{array}$ & $\begin{array}{c}17,45 \\
(15,35 ; 18,55) \\
\mathrm{p}_{1-4}<0,001^{*} \\
\mathrm{p}_{2-4}=0,002^{\star} \\
\mathrm{p}_{3-4}=0,003^{\star}\end{array}$ \\
\hline \multicolumn{5}{|c|}{ Критерій Краскела - Уолліса, p (H=24,53; p<0,001*) } \\
\hline ЛФ, Од/л & $\begin{array}{c}255,70^{\#} \\
(242,45 ; 255,70)\end{array}$ & $\begin{array}{c}492,50^{\#} \\
(359,00 ; 504,50) \\
\mathrm{p}_{1-2}<0,001^{\star}\end{array}$ & $\begin{array}{c}387,50^{\#} \\
(324,00 ; 426,00) \\
p_{1-3}<0,001^{*} \\
p_{2-3}>0,05\end{array}$ & $\begin{array}{c}624,00^{\#} \\
(602,50 ; 693,00) \\
\mathrm{p}_{2-4}=0,002^{*} \\
\mathrm{p}_{2-4}<0,001^{*}\end{array}$ \\
\hline \multicolumn{5}{|c|}{ Критерій Краскела - Уолліса, p $(26,57 ;$ p<0,001*) } \\
\hline АлАТ, Од/л & $\begin{array}{c}76,30 \\
(66,65 ; 83,45)\end{array}$ & $\begin{array}{c}315,50^{\#} \\
(275,50 ; 333,50) \\
\mathrm{p}_{1-2}<0,001^{\star}\end{array}$ & $\begin{array}{c}196,00^{\#} \\
(179,00 ; 202,50) \\
\mathrm{p}_{1-3}<0,001^{*} \\
\mathrm{p}_{2-3}<0,001^{*}\end{array}$ & $\begin{array}{c}544,50^{\#} \\
(504,50 ; 615,50) \\
\mathrm{p}_{1-4}<0,001^{*} \\
\mathrm{p}_{2-4}<0,001^{*} \\
\mathrm{p}_{3-4}<0,001^{*}\end{array}$ \\
\hline \multicolumn{5}{|c|}{ Критерій Краскела - Уолліса, p (H=29,09; p<0,001*) } \\
\hline
\end{tabular}

Примітка. 1. \# - статистично значущі результати при порівнянні статевозрілих і статевонезрілих щурів.

2. * - статистично значущі результати.

дані при ізольованій дії тютюнового диму та на $63,1 \%(p=0,002)-$ показник за умови ізольованої дії натрій глутамату. При цьому ізольоване введення натрій глутамату не зумовило достовірного підвищення активності ЛФ у сироватці крові порівняно з контрольними тваринами.

У статевонезрілих щурів за умови пасивного тютюнокуріння активність ЛФ у сироватці крові вірогідно підвищилася на 92,6 \% відносно контрольної групи. Пасивне тютюнокуріння на тлі застосування натрій глутамату супроводжувалося більш вираженим її зростанням (у 2,4 раза; $\mathrm{p}<0,001)$ щодо контрольної групи, що на 26,7 \% $(p=0,002)$ перевищувало дані при ізольованій дії тютюнового диму та на 61,0% ( $p=0,003)$ - показник за умови тривалого введення натрій глутамату. При цьому ізольоване введення натрій глутамату зумовило достовірне підвищення активності ЛФ у сироватці крові на 51,5 \% порівняно $з$ контрольними тваринами.

У віковому аспекті інтенсивність змін активності ЛФ у сироватці крові перевищувала показники статевозрілих щурів за умови пасивного тютюнокуріння на 54,3 \%, при тривалому введенні натрій глутамату - на 21,6 \%, за умови пасивного тютюнокуріння на тлі застосування натрій глутамату - на 32,1 \% відповідно.

За умови пасивного тютюнокуріння активність АлАТ у сироватці крові статевозрілих щурів вірогідно підвищилася у 2,6 раза відносно контрольної групи. Пасивне тютюнокуріння на тлі застосування натрій глутамату супроводжувалося більш вираженим її зростанням (у 4,5 раза; p<0,001) щодо контрольної групи, що на 68,8 \% ( $<<0,001)$ перевищувало дані при ізольованій дії тютюнового диму та у 2,7 раза ( $p<0,001)$ - показник за умови ізольованої дії натрій глутамату. При цьому ізольоване введення натрій глутамату зумовило достовірне підвищення активності АлАТ у сироватці крові на 62,5 \% порівняно 3 контрольними тваринами.

У статевонезрілих щурів за умови пасивного тютюнокуріння активність АлАТ у сироватці крові вірогідно підвищилася у 4,1 раза відносно контрольної групи. Пасивне тютюнокуріння на тлі застосування натрій глутамату супроводжувалося більш вираженим її зростанням (у 7,1 раза; $p<0,001$ ) щодо контрольної групи, що на 72,6 \% ( $<<0,001)$ перевищувало дані при ізольованій дії тютюнового диму та у 2,8 раза $(p<0,001)$ - показник за умови тривалого введення натрій глутамату. При цьому ізольоване введення натрій глутамату зумовило достовірне підвищення активності АлАТ у сироватці крові у 2,6 раза порівняно з контрольними тваринами.

У віковому аспекті інтенсивність змін активності АлАТ у сироватці крові перевищувала показники статевозрілих самців за умови пасивного тютюнокуріння на 148,9 \%, при тривалому введенні натрій глутамату - на 94,4 \%, за умови пасивного тютюнокуріння на тлі застосування натрій глутамату - на 267,6 \% відповідно. 
Отже, натрій глутамат посилює токсичний вплив тютюнового диму на печінку, що проявляється більш вираженими порушеннями її фрункціонального стану (вірогідно вищі значення активності АлАТ і ЛФ; достовірно нижчі значення вмісту загального білірубіну в сироватці крові) за умови комбінованої дії тютюнового диму та натрій глутамату відносно ізольованої дії тютюнового диму. Причиною цього може бути надмірне навантаження печінки іонами амонію внаслідок зростання рівня глутамату [19]. Крім того, натрій глутамат зумовлює утворення вільних радикалів, які реагують із поліненасиченими жирними кислотами клітинних мембран, що може призвести до порушення як плазматичної, так і мітохондріальної мембран та виходу внутрішньоклітинних ензимів [21, 22].

ВИСНОВКИ. 1. Пасивне тютюнокуріння на тлі застосування натрій глутамату супроводжується цитолізом гепатоцитів, що підтверджується зростанням активності аланінамінотрансферази у сироватці крові статевозрілих щурів
( 4 4,5 раза; $p<0,001)$ відносно контрольної групи, що на $68,8 \%(p<0,001)$ вище цього показника за умови ізольованої дії тютюнового диму. У віковому аспекті більш виражений синдром цитолізу розвивається у статевонезрілих щурів, що підтверджується переважанням інтенсивності змін аланінамінотранссрерази на 267,6 \%.

2. Пасивне тютюнокуріння на тлі застосування натрій глутамату супроводжується вираженим зменшенням вмісту загального білірубіну в сироватці крові статевозрілих щурів (на 55,3 \%; р<0,001) відносно контрольної групи, що на $31,0 \%(p=0,002)$ нижче цього показника при ізольованій дії тютюнового диму, та вираженим зростанням активності лужної фоосратази (у $2,1$ раза; $p<0,001)$ щодо контрольної групи, що на 53,2 \% (p<0,001) вище даного показника за умови ізольованої дії тютюнового диму. У віковому аспекті більш виражений синдром холестазу розвивається у статевонезрілих щурів, що підтверджується переважанням інтенсивності змін активності лужної фоосратази на 32,1 \% відповідно.

\section{СПИСОК ЛІТЕРАТУРИ}

1. World Health Organization. Tobacco, WHO: Geneva, Switerland, 2019. - Access mode : https://www. who. int/news-room/fact-sheets/detail/tobacco

2. Pinkas J. The prevalence of tobacco and E-cigarette use in Poland: A 2019 Nationwide Cross-Sectional Survey / J. Pinkas, D. Kaleta, W. S. Zgliczy'nski // Int. J. Environ. Res. Public Health. - 2019. - No. 16. - 4820. DOI:10.3390/ijerph16234820.

3. Ещенко К. Н. Сердечно-сосудистая система и курение /К. Н. Ещенко, А. В. Жадан, Н. Ф. Шустваль // Ліки України. - 2013. - № 4. - С. 12-19.

4. Особенности распространения табакокурения среди школьников Украины / Н. С. Полька, О. В. Добрянская, Е. И. Турос [и др.] // Клініч. педіатрія. - 2016. № 6 (74). - С. 27-29.

5. Ільченко С. І. Персоніфрікований підхід до профрілактики тютюнокуріння у підлітків / С. І. Ільченко, А. О. Фіалковська // ScienceRise: Medical Science. 2018. - № 1 (21). - C. 35-38.

6. Куріння, вживання алкоголю та наркотичних речовин серед підлітків, які навчаються: поширення й тенденції в Україні : за результатами дослідження 2019 року в рамках міжнародного проекту “Європейське опитування учнів щодо вживання алкоголю та інших наркотичних речовин - ESPAD" / [O. М. Балакірєва (кер. авт. кол.), Д. М. Павлова, Н.-М. К. Нгуєн та ін.]. - К. : ТОВ “ОБНОВА КОМПАНІ", 2019. - 214 с.
7. Пікас О. Б. Про стан куріння цигарок у сучасних умовах, його вплив на виникнення захворювань в організмі людини / О. Б. Пікас // Буковин. мед. вісн. 2015. - 19, № 4. - C. 227-230.

8. Association between smoking and non-alcoholic fatty liver disease: A systematic review and meta-analysis / A. Akhavan Rezayat, M. Dadgar Moghadam, M. Ghasemi Nour [et al.] // SAGE Open Med. 2018;6: 2050312117745223. DOI:10.1177/2050312117745223.

9. Cigarette smoking exacerbates nonalcoholic fatty liver disease in obese rats / L. Azzalini, E. Ferrer, L. N. Ramalho [et al.] // Hepatology. - 2010. - No. 51 (5). P. 1567-7156.

10. Nonalcoholic Steatohepatitis Clinical Research Network. Smoking and severity of hepatic fibrosis in nonalcoholic fatty liver disease / C. O. Zein, A. Unalp, R. Colvin [et al.] // J. Hepatol. - 2011. - No. 54 (4). P. 753-759.

11. Dass B. P. Changes in hematological and biochemical parameters in smokeless tobacco (ST) Chewers in Costal Belt of Andhra Pradesh, India / B. P. Dass, P. Jaganmohan, P. Sravanakumar // European Journal of Biological Sciences. - 2013. No. 5 (1). - P. 29-33.

12. Effects of coffee, smoking and alcohol on liver function tests: a comprehensive cross-sectional study / E. S. Jang, S. Heong, S. Hwang [et al.] // BMC. Gastroenterology. - 2012. - No. 12 (1). - P. 145. 
13. Бевзо В. В. Дослідження токсикодинаміки глутамату натрію на організм щурів за умов тривалого його введення / В. В. Бевзо // Клініч. та експерим. патологія. - 2016. - 15, № 2 (56), ч. 2. - С. 13-16.

14. Лизурчик Л. В. Влияние табачного дыма на содержание токсичных элементов в организме крыс / Л. В. Лизурчик, Е. В. Шейда // Вестн. ОГУ. - 2014. № 6 (167). - C. 71-74.

15. Exposure to secondhand smoke impairs fracture healing in rats / H. A. Santiago, A. Zamarioli, M. D. Souisa Neto [et al.] // Clin. Orthop. Relat. Res. 2017. No. 475 (3). - Р. 894-902.

16. Влияние глипролинов на структурно-фрункциональное состояние слизистой оболочки желудка и массу тела крыс в условиях длительного введения глутамата натрия / Т. М. Фалалеева, Г. Е. Самонина, Т. В. Береговая [и др.] // Фізика живого. - 2010. - 18, № 1. - C. 154-159.

17. Jansen T. Direct antioxidant properties of bilirubin and biliverdin. Is there a role for biliverdin reductase? I T. Jansen, A. Daiber // Front Pharmacol. -2012. - No. 3. P. 30.

18. Alsalhen K. S. Effect of cigarette smoking on liver functions: a comparative study conducted among smokers and non-smokers male in El-beida City, Libya / K. S. Alsalhen, R. D. Abdalsalam // International Current Pharmaceutical Journal. 2014. - No. 3 (7). - P. 291-295.

19. Tawfik M. S. Adverse effects of monosodium glutamate on liver and kidney functions in a dult Rats and Potential Protective Effect of Vitamins C and E / M. S. Tawfik, N. Al-Badr // Food and Nutrition Sciences. 2012. - No. 3. - P. 651-659.

20. Коркин А. Л. Диагностическое значение лабораторных показателей холестаза и ферментативного профиля трансаминаз для оценки степени бактериохолии у пациентов с заболеваниями желчных путей / А. Л. Коркин, Е. А. Угорелова, А. В. Грибачева // Вестн. СурГУ. Медицина. -2016. - № 4 (30). - С. 26-29.

21 . Alterations in the lipid profile and liver enzymes of rats treated with monosodium glutamate / B. S. Okediran, A. E. Olurotimi, S. A. Rahman [et al.] // Sokoto Journal of Veterinary Sciences. - 2014. - No. 12 (3). P. 42-46.

22. The indices of endogenous intoxication in rats with carrageenan solution consumption / I. Krynytska, M. Marushchak, O. Svan [et al.] // Georgian Med. News. 2018. - No. 279. - P. 196-200.

\section{REFERENCES}

1. (2019). World Health Organization. Tobacco; WHO: Geneva, Switerland. Retrieved from: https://www. who. int/news-room/fact-sheets/detail/tobacco

2. Pinkas, J., Kaleta, D., \& Zgliczy'nski, W.S. (2019). The prevalence of tobacco and E-cigarette use in Poland: A 2019 Nationwide Cross-Sectional Survey. Int. J. Environ. Res. Public Health, 16, 4820.

3. Yeshchenko, K.N., Zhadan, A.V., \& Shustval, N.F. (2013). Serdechno-sosudistaya sistema i kureniye [Cardiovascular system and smoking]. Liky Ukrainy - Medicines of Ukraine, 4 (170), 12-17 [in Russian].

4. Polka, N.S., Dobryanskaya, O.V., Turos, Ye.I., Dardynskaya, I.V., \& Zeygler, D. (2016). Osobennosti rasprastraneniya tabakokureniya sredi shkolnikov Ukrainy [Features of the spread of smoking among school-children of Ukraine]. Zdorovye rebenka - Child's Health, 6 (74), 27-29 [in Russian].

5. Ilchenko, S.I., \& Fialkovska, A.O. (2018). Personifikovanyy pidkhid do profilaktyky tiuiyunokurinnia u pidlitkiv [Personalized approach to tobacco prevention in adolescents]. Scientific Journal "Science Rise: Medical Science", 1 (21), 35-38 [in Ukrainian].

6. Balakiryeva, O.M., Pavlova, D.M., Nhuyen, N.M., Levtsun, O.H., Pyvovarova, N.P., Sakovych, O.T., \& Flyarkovska, O.V. (2019). Kurinnia, vzhyvannia alkoholiu ta narkotychnykh rechovyn sered pidlitkiv, yaki navchaiutsia: poshyrennia y tendentsii v Ukraini: Za rezultatamy doslidzhennia 2019 roku v ramkakh mizh- narodnoho proektu "Yevropeyske opytuvannia uchniv shchodo vzhyvannia alkoholiu ta inshykh narkotychnykh rechovyn-ESPAD". [Smoking, alcohol and drug use among adolescents studying: prevalence and trends in Ukraine: According to the results of a 2019 study within the international project "European survey of students on alcohol and other drug use-ESPAD"]. Kyiv: Polihrafichnyi tsentr Foliant [in Ukrainian].

7. Pikas, O.B. (2015). Pro stan kurinnia tsyharok u suchasnykh umovakh, yoho vplyv na vynyknennia zakhvoriuvan $v$ orhanizmi liudyny [On the state of cigarette smoking in modern conditions, its impact on the occurrence of diseases in the human body]. Bukovynskyi medychnyi visnyk - Bukovynian Medical Bulletin, 19, 4, 227-230. [in Ukrainian].

8. Akhavan Rezayat, A., Dadgar Moghadam, M., Ghasemi, Nour. M., Shirazinia, M., Ghodsi, H., Rouhbakhsh Zahmatkesh, M.R., Tavakolizadeh Noghab, I.M., Hoseini, B., Akhavan Rezaya, K. (2018). Association between smoking and non-alcoholic fatty liver disease: A systematic review and meta-analysis. SAGE Open Med, 6, Retrieved from: doi:10.1177/2050312117745223.

9. Azzalini, L., Ferrer, E., Ramalho, L.N., Moreno, M., Domínguez, M. \& Colmenero, J. (2010). Cigarette smoking exacerbates nonalcoholic fatty liver disease in obese rats. Hepatology, 51 (5), 1567-7156.

10. Zein, C.O., Unalp, A., Colvin, R., Liu, Y.C. \& McCullough, A.J. (2011). Nonalcoholic Steatohepatitis 
Clinical Research Network. Smoking and severity of hepatic fibrosis in nonalcoholic fatty liver disease. $\mathrm{J}$. Hepatol., 54 (4), 753-759.

11. Dass, B.P., Jaganmohan, P. \& Sravanakumar, P. (2013). Changes in hematological and biochemical parameters in smokeless tobacco (ST) Chewers in Costal Belt of Andhra Pradesh, India. European Journal of Biological Sciences, 5 (1), 29-33.

12. Jang, E.S., Heong, S., Hwang, S., Kim, H., Ahn, S., Lee, J. \& Lee, D. (2012). Effects of coffee, smoking and alcohol on liver function tests: a comprehensive cross-sectional study. BMC. Gastroenterology, 12 (1), 145.

13. Bevzo, V.V. (2016). Doslidzhennia toksykodynamikiv hlutamatu natriiu na tryvalist shchuriv dlia tryvaloho yoho vvedennia [Investigation of the toxi codynamics of glutamate sodium in rats under the condition of its long introduction]. Klinichna ta eksperymentalna patolohiia - Clinical and Experimental Pathology, XV, 2 (56), 2, 13-16 [in Ukrainian].

14. Lizurchik, L.V., \& Sheyda, E.V. (2014). Vliyanie tabachnogo dyma na soderzhaniye toksichnykh elementov $v$ organizme krys [Effect of tobacco smoke on the content of toxic elements in the body of rats]. Vestnik OGU - Journal of the Orenburg State University, 6 (167), 71-74 [in Russian].

15. Santiago, H.A., Zamarioli, A.,Sousa Neto, M.D., \& Volpon, J.B. (2017). Exposure to secondhand smoke impairs fracture healing in rats. Clin. Orthop. Relat. Res., 475(3), 894-902.

16. Falaleeva, T.M., Samonina, H.Ye., Berehova,T.V., Dzyubenko, N.V., \& Andreeva, L.A. (2010). Vliyanye gliprolynov na strukturno-funktsyonalnoe sostoyanye slyzystoy obolochky zheludka i massa tela krys v uslo- viyakh dlitelnogo vvedenniya hlutamata natriya. Fizyka zhyvoho - Physics of the Living, 18 (1), 154-159 [in Russian].

17. Jansen, T., \& Daiber, A. (2012). Direct antioxidant properties of bilirubin and biliverdin. Is there a role for biliverdin reductase? Front. Pharmacol., 3, 30.

18. Alsalhen, K.S., \&Abdalsalam, R.D. (2014). Effect of cigarette smoking on liver functions: a comparative study conducted among smokers and non-smokers male in El-beida City, Libya. International Current Pharmaceutical Journal, 3 (7), 291-295.

19. Tawfik, M.S., \&Al-Badr, N. (2012). Adverse effects of monosodium glutamate on liver and kidney functions in adult rats and potential protective effect of vitamins $C$ and E. Food and Nutrition Sciences, 3, 651-659.

20. Korkin, A.L., Ugorelova, Ye.A., \& Gribacheva, A.V. (2016). Diagnosticheskoye znacheniye laboratornykh pokazateley kholestaza i fermentativnogo profilya transaminaz dlya otsenki stepeni bakteriokholii u patsiyentov s zabolevaniyami zhelchnykh putey [Diagnostic value of laboratory parameters of cholestasis and enzymatic profile of transaminases for assessing the degree of bacteriocholia in patients with biliary tract diseases.]. Vestnik SurGU. Meditsina-Bulletin of SURSU. Medicine, 4 (30), 26-29 [in Russian].

21. Okediran, B.S., Olurotimi, A.E., Rahman, S.A., Michael, O.G. \& Olukunle, J.O. (2014). Alterations in the lipid profile and liver enzymes of rats treated with monosodium glutamate. Sokoto Journal of Veterinary Sciences, 12 (3), 42-46.

22. Krynytska, I., Marushchak, M., Svan, O., Akimova, V., Mazur, L. \& Habor, H. (2018). The indices of endogenous intoxication in rats with carrageenan solution consumption. Georgian Med. News, 279, 196-200.

N. V. Hetsko, T. Ya. Yaroshenko

I. HORBACHEVSKY TERNOPIL NATIONAL MEDICAL UNIVERSITY

\section{FEATURES OF THE FUNCTIONAL STATE OF THE LIVER IN RATS OF DIFFERENT AGE WITH MODELED SECONDHAND TOBACCO SMOKING COMBINED WITH ADMINISTRATION OF MONOSODIUM GLUTAMATE}

\section{Summary}

Introduction. Every year tobacco smoking kills more that 8 million people all over the world; 1.2 of them are secondhand smokers. Meanwhile, the characteristic feature of modern food technologies is the usage of food supplements which are not always safe for human health.

The aim of the study - to investigate the changes of the liver functional state in blood serum of rats of different age in case of secondhand tobacco smoking combined with administration of monosodium glutamate.

Research Methods. Experiments were conducted on 32 outbred mature white male-rats 180-200 g weight and 32 outbred immature white male-rats 60-80 g weight. Each group of animals was divided into four subgroups: $I$ - control ( $n=8)$; II - rats with modeled secondhand tobacco smoking $(n=8)$; III - rats, which were injected with monosodium glutamate $(n=8) ; \mathrm{IV}$ - rats with modeled secondhand tobacco smoking combined with the monoso- 
dium glutamate injection ( $n=8)$. In the blood serum of rats, the content of the general bilirubin, the activity of alkaline phosphatase (ALP) and the activity of the alaninaminotransferase (ALT) were determined.

Results and Discussion. In case of secondhand tobacco smoking in the blood serum of mature rats, the content of the general bilirubin significantly decreased by $35.3 \%$, the ALP activity significantly increased by $38.3 \%$, the activity of ALT was significantly increased by 2.6 times, which indicated a violation of the functional state of the liver and the development of cytolysis and cholestasis. Secondhand tobacco smoking on the background of the use of monosodium glutamate was accompanied by a decrease in the content of the total bilirubin by $55.3 \% ; p<0.001$ vs control group, which is $31.0 \%(p=0.002)$ below this indicator with an isolated action of tobacco smoke; an increase in ALP activity by 2.1 times; $p<0.001$ vs control group, which is $53.2 \%(p<0.001)$ exceeded the data with an isolated action of tobacco smoke; an increase in the activity of ALT by 4.5 times; $p<0.001$ vs control group, which is $68.8 \%(p<0.001)$ exceeded the data with an isolated action of tobacco smoke. In immature rats, the intensity of changes of biochemical markers of the liver functional state exceeds the rates of mature rats.

Conclusions. The results indicate that monosodium glutamate enhances the toxic effect of tobacco smoke on the liver, which is manifested by more pronounced changes in the biochemical markers of its functional state in case of the combined effect of tobacco smoke and monosodium glutamate versus to the isolated tobacco smoke action. In the age aspect, more pronounced changes are observed in immature rats.

KEY WORDS: secondhand tobacco smoking; monosodium glutamate; functional state of the liver; biochemical markers.

Отримано 30.08.21

Адреса для листування: Н. В. Гецько, Тернопільський національний медичний університет імені І. Я. Горбачевського мОз України, майдан Волі, 1, Тернопіль, 46001, Україна, e-mail: nadikage@ukr.net. 